\title{
ADALÉKOK JANUS PANNONIUS DE STELLA AESTIVO MERIDIE VISA CÍMÜ ELÉGIÁJÁNAK ÉRTELMEZÉSÉHEZ
}

\begin{abstract}
Mindmáig nem jutott nyugvópontra a kutatás azon kérdésben, hogy milyen égitest tűnik föl Janus Pannonius De stella aestivo meridie visa című elégiájában. Bollók János az égitestet az 1462 nyarán Kínában megfigyelt üstökössel azonosította. Álláspontját azonban kétkedés fogadta, s az elégiát elemző újabb tanulmányok a Venus bolygóval való azonosítás mellett foglalnak állást. Tanulmányunkban a kutatásban eleddig figyelmen kívül hagyott irodalmi párhuzamok vizsgálatával amellett érvelünk, hogy a leírás üstököst kíván ábrázolni. Megvizsgáljuk Tito Vespasiano Strozzi Borsias című eposzának hasonló tárgyú leírását, s kimutatjuk, hogy a kedvező hatású üstökösökről vallott asztrológiai fölfogása azonos volt Januséval. Ezt erősítik meg a Matteo Maria Boiardo eclogáiban föllelhető, Janustól származó kölcsönzések is. Úgyszintén figyelmen kívül hagyta a kutatás T. Calpurnius Siculus 1. eclogájának jótékony hatású üstökösét. A szövegszerű megfelelések vizsgálatával megkíséreljük igazolni, hogy ez az ecloga Janus elégiájának egyik fontos előképe volt, s hatása nemcsak az üstökös leírásában, hanem az elégia aranykori motívumokat megidéző fohászkodásában is kimutatható.

Kulcsszavak: Janus Pannonius, Calpurnius Siculus, Claudius Claudianus, Tito Vespasiano Strozzi, Matteo Maria Boiardo, humanista elégia, bukolikus költészet, antik és reneszánsz asztrológia
\end{abstract}

Miféle égitest tündököl Janus Pannonius 1462 nyarán keletkezett elégiájában? Ebben a kérdésben mindmáig nem jutott nyugvópontra a kutatás. Bartha Lajos amellett foglalt állást, hogy a Venus 584 naponként ismétlődő, 1462-ben augusztus 10. és 20. közé eső inflammációja ihlette a leírást. Az inflammációs időszakokban ugyanis a bolygó fényessége kétszeresére növekedik, s kedvező időjárási viszonyok között nappal is megfigyelhető. ${ }^{1}$ Bollók János arra a következtetésre jutott, hogy az égitest az 1462-ben Kínában megfigyelt üstökössel (C/1462 M1) azonos, mely június 29. és július 16. között volt látható. ${ }^{2}$ Kiszámított pályája: Cassiopeia, Cepheus-Camelopardalis, Ursa Maior, Leo Minor. ${ }^{3}$ Jóllehet Bollók az antik asztrológiai irodalom elmélyült ismerőjeként, részletekbe menő elemzéssel, saját számításokat végezve alakította ki álláspontját, eredményeit a kutatás kétkedve fogadta. A kételyeket alaposan taglalja Jankovits László tanulmánya. ${ }^{4}$ A legsúlyosabb ellenérv, miként azt maga Bollók is hangsúlyozta, hogy az említett üstököst csak kínai forrásokból ismerjük, európai följegyzés nem maradt ránk. Említsük meg itt, hogy az ún. Gusztini Kódex beszámol ebből az időből egy üstökösszerű égi jelenségről, mely Lengyelország fölött tűnt föl, keresztet és kardot formázva. E jelenség

* Itt mondok köszönetet Mayer Gyulának a készülő tanulmányhoz fűzött értékes megjegyzéseiért.

1 Bartha L.: Janus Pannonius két csillagászati verse. Itk 82 (1978) 340-345.

2 Bollók J.: Asztrális misztika és asztrológia Janus Pannonius költészetében. Budapest (2003) 67-85.

3 G. W. Kronk: Cometography. A Catalog of Comets I. Cambridge (1999) 282.

${ }^{4}$ Jankovits L.: A költő, a király és a csillag. In: „Köztes-Európa” vonzásában. Ünnepi tanulmányok Font Márta tiszteletére. Szerk. Bagi D. - Fedeles T. - Kiss G. Pécs (2012) 233-244. 
1462-re való datálása azonban bizonytalan, ${ }^{5} \mathrm{~s}$ maga a krónika sem éppen megbízhatóságáról nevezetes. ${ }^{6}$ Ha tehát Janus valóban a C/1462 M1 üstököst írná le, az költeményét egyedülálló csillagászattörténeti dokumentummá tenné. (Korántsem példátlan viszont, hogy a XV. századból egy-egy üstökösről csak egyetlen európai tudósítás maradt ránk. ${ }^{7}$ Kételyek merültek föl Janus csillagászati képzettségét illetően is, hiszen leírása, ha valóban üstökösről van szó, föltételezi, hogy a költő képes volt önálló műszeres megfigyelések és csillagászati számítások elvégzésére. Mindezeket mérlegelve Jankovits arra hajlik, hogy Bartha Lajos magyarázatát tartsa valószínűbbnek. Maga Bartha is kitartott először 1978-ban publikált megoldási javaslata mellett. 2016-ban közzétett ismeretterjesztő tanulmányában változtatás nélkül megismételte álláspontját. Bollók elemzését nem cáfolta, mi több, egyáltalán tudomást sem vett róla. ${ }^{8}$ Bartha azonosítását fogadta el újabban Orbán Áron is a Janus asztrológiai ismereteiről szóló tanulmányában. ${ }^{9}$ Zsoldos Endre, aki a változócsillagászat magyarországi kezdeteiről írott értekezésében csak futólagosan tér ki a költeményre, mindkét föltevéssel szemben szkeptikus, s egy harmadik lehetőséget latolgat: „Janus nem látott semmit, csak az általa igen nagyra becsült Claudianus nyomán az égen nappal látható csillagot toposzként használta." ${ }^{10}$

A következőkben tehát a kutatásban eddig figyelembe nem vett humanista és klasszikus irodalmi párhuzamok alapján amellett érvelünk, hogy Janus üstököst kívánt megörökíteni, mégpedig olyat, amelyről föltételezte, vagy legalábbis remélte, hogy nem ártalmas, hanem jótékony hatású. Így értette nemcsak Bollók János, hanem már Janus régi kommentátora, Kovásznai Sándor is, aki szerint az üstökös jóindulatú „stella Iovialis", mely képes semlegesíteni a Saturnus ártalmas befolyását. ${ }^{11}$ Elemzésünket az irodalmi párhuzamokra korlátozzuk, asztronómiai és asztrológiai részletkérdésekben nem foglalunk állást.

Bartha Lajos elméletének, a Venus bolygóval való azonosításnak, melyet Bollók „kicsit kalandos feltevés”-nek ítélt, mindenesetre megvannak a gyönge pontjai. Amellett, hogy a leírást a teljes elégia szövegkörnyezetéből kiszakítva értelmezi, Janusról - Bollók álláspontjával homlokegyenest ellenkező módon - föltételezi, hogy még az Esthajnalcsillagot és annak helyzetét sem ismerte föl az égbolton, pusztán annak megnövekedett fényereje miatt, ami a csillagászatban való teljes járatlanságról tanúskodnék. Ebből következnék azután a költő tétovázása, hogy vajon a Venus, a Iuppiter vagy valamilyen új csillag tündöklik-e az égen:

${ }^{5}$ A. N. Vyssotsky: Astronomical Records in the Russian Chronicles from 1000 to 1600 A. D. Lund (1949) 36.

${ }^{6}$ Lásd Font M.: A kijevi évkönyv mint történeti forrás. Történeti Szemle 33 (1991) 75.

7 Lásd Kronk: i. m. (3. j.) 260-293.

${ }^{8}$ Bartha L.: Csillag-csodák. Vénusz a nappali égen. Ponticulus Hungaricus 20/7 (2016). https:// ponticulus.hu/rovatok/hidverok/bartha-lajos-csillagcsodak.html.

9 Orbán Á.: The nature of astrology in Janus Pannonius' works composed in Hungary. ActaAntHung 54 (2014) 215-234.

10 Zsoldos E.: A változócsillagászat kezdete Magyarországon. Doktori értekezés. Budapest (2010) 44.

11 Z. Dalloul: Kovásznai Sándor, az elfeledett Janus-kommentátor. Doktori értekezés. Szeged (2008) 72. 
Sed tu - sive Iovem mavis te forte vocari, grata est Idaliae seu tua flamma deae, sive novum caelo modo te deus addidit ignem, ac solis fessae iussit adesse facifelix cui soli fas est haud cedere Phoebo, non tantum noctis quae potes esse decus, nil dirum, nil triste feras, sed lumine dextro pelle procul quicquid fata sinistra parant. (Eleg. 22, 15-22) ${ }^{12}$

Mindegyik bíráló figyelmen kívül hagyni látszik a 15-16. sor („Te azonban - akár esetleg azt akarod inkább, hogy Iuppiternek hívjanak, akár az idaliumi istennőnek kedves a te lángod...") értelmezési nehézségeit. Márpedig Bollók meggyőzően bizonyította, hogy ez a mondat egy kuriózumszámba menő, ám Janus által okvetlenül ismert asztrológiai szövegből, Serviusnak az Aeneis 10, 272-273. sorához (non secus ac liquida si quando nocte cometae / sanguinei lugubre rubent...) füzött kommentárjából magyarázható:

Plinius etiam Secundus dicit, cometas stellas esse naturales, quae apparent certis temporibus. Itemque hoc quoque commemorat, cometas fieri de planetis quinque, unde interdum bonum, interdum pessima significant; nam si de Venere aut Iove fiant, optima praenuntiant, si de Marte aut Saturno, deteriora; nam Mercurialis talis est semper, qualis ille cui cohaeret. ${ }^{13}$

Janus tehát abban reménykedik, hogy az üstökös valamely jótékony bolygó, vagy a Iuppiter (az asztrológiában: fortuna maior), vagy a Venus (fortuna minor) természetét hordozza, s ezáltal képes - kedvező fényszögbe kerülve - a kártékony Mars (infortuna minor) és a még kártékonyabb Saturnus (infortuna maior) hatását közömbösíteni.

Tudomásunk szerint a szakirodalomban még nem esett szó arról, hogy igen hasonló üstököselmélettel találkozhatunk Janus idősebb költőbarátja, Tito Vespasiano Strozzi Borsias című eposzában, melyen az 1460-as évek elején kezdett dolgozni. ${ }^{14}$ A Borso d'Este hatalomra kerülését (1450. október 1.) és ünnepélyes ferrarai bevonulását részletező jelenet az antik panegyrikusokban nem ritka epiphanialeírások számos megszokott motívumát fölhasználja. ${ }^{15} \mathrm{Az}$ új uralkodó adventusát égi fényáradat (cecidit manifestus

12 Janus szövegét az alábbi kiadás szerint idézzük: Iani Pannonii Opera quae manserunt omnia. Vol. II. Elegiae. Fasc. 1. Textus. Edidit, praefatus est et apparatu critico instruxit Iulius Mayer, similia addidit Ladislaus Török. Budapest (2014).

13 Bollók: i. m. (2. j.) 79.

${ }^{14}$ Die Borsias des Tito Strozzi. Ein lateinisches Epos der Renaissance. Erstmals herausgegeben, eingeleitet und kommentiert von Walther Ludwig. München (1977) 38. Az eposzról újabban lásd Szörényi L.: Magyar vonatkozások Tito Strozzi Borsias című eposzában. In: Irodalomtörténet, tudománytörténet, eszmetörténet. Tanulmányok Tarnai Andor halálának 25. évfordulójára. Szerk.: Papp I. Budapest (2020) 181-189.

15 Az adventusról lásd Borzsák I.: „Pogány” Adventus - keresztény Ádvent. AntTan 44 (2000) 91-100 = Dragma IV. Budapest (2000) 7-18. 
ab aethere fulgor, 3, 199), csapadék nélküli szivárvány (nullis effusis imbribus ante / arcus ab Aurora veniens, 3, 208-209), teljes szélcsönd (tum venti posuere omnes, 3, 211), az évszakok rendjét fölborító tavaszias időjárás, hirtelen kinyíló virágok, új lombot hajtó, s azonmód gyümölcsöt is termő fák (ver conata novum variosque reducere flores; / atque novas ramis frondes mirantibus arbor / protulit ac laetos alieno in tempore foetus, 3, 215-217) jelzik. Föltűnő a hasonlóság Strozzi egy korábban íródott, de szintén Borso érkezését ünneplő elégiájával (De adventu Borsii in genialeis agros, Erot. 4,10). ${ }^{16}$ Ebben is egymást követik a tündöklő égbolt (novo diffusum lumine coelum, 1), a szélcsönd (liquidus nullis agitetur flatibus aer, 3), az őszi hervadásban hirtelen virágba boruló föld (posito tellus squallore virescat / et se purpureis floribus induerit, 5) és a kizöldülő fák (exultet ramis frondentibus arbos, 7) képei. Vagyis Strozzi, mondhatni, korábbi elégiáját dolgozta át hexameterekbe. Leírását egyetlen, de a hasonló tárgyú panegyrikusokban annál szokatlanabb motívummal bővítette, s ezt rögtön a mintegy 30 soros adventusjelenet elejére helyezte: a Leonello d'Este halálát előrejelző, baljós égi tünemények helyett más, áldásos hatású üstökösök jelennek meg az égen, melyek csodálatos módon egyesítik magukban a Venus és a Iuppiter jótékony erejét, s ezáltal következhetik be a természet bámulatos kivirágzása. A kométák keletkezéséről és fajtáiról tehát ugyanazon, Serviusnál olvasható elméletet vallotta, melyet magyar költőtársa, ám ezt némileg bővebben ki is fejti:

At Leonellei praenuntia sydera casus
visa comam nuper praesago extendere tractu
deseruere polum; atque alios fulgere cometas,
aurea Luciferi dea quos Orientis ad oras
mista Iovi fertur partu effudisse benigno,
vidimus.

(Bors. 3, 200-205)

A Leonello uralmának végét jövendölő, vészterhes égitest, melyre Strozzi utal, valószínűleg nem a képzelet szüleménye. Azonos lehet a C/1449 Y1 üstökössel, mely Kína fölött 1449. december 20-án tünt föl. ${ }^{17}$ Erről - igaz, csak egyetlen - európai följegyzés is ránk maradt. A kor egyik legtekintélyesebb csillagásza, Ficino és Cusanus közeli barátja, Paolo Toscanelli 1449. december 26-án, hajnaltájt észlelte először, utoljára pedig 1450. február 13-án látta. ${ }^{18}$ Más különös égi jelenségről viszont ebből az évből nem tudunk, nyilvánvaló tehát, hogy a jóindulatú üstökösök képének beillesztése az adventusleírásba pusztán költői lelemény.

Nem tudjuk, hogy Strozzi ismerte-e Janus elégiáját a Borsias e jelenetének megalkotásakor. Föltűnő viszont, hogy unokaöccse, Matteo Maria Boiardo 1463-1464-re

${ }^{16}$ Strozzi elégiáját az alábbi kiadás alapján idézzük: Tito Vespasiano Strozzi: Poesie latine tratte dall'Aldina e confrontate coi codici. A cura di Anita della Guardia. Modena (1916).

17 Kronk: $i . m$. (3. j.) 272.

18 J. L. Jervis: Cometary Theory in Fifteenth Century Europe. Dordrecht (1985) 58-60. 
datálható 4. eclogájában (Vasilicomantia), mely szintén Borso uralmának aranykori vonásait részletezi, több Janus-reminiszcenciát is találunk, $\mathrm{s}$ az egyik éppen a De stellából való: Fulva Cleonaeo iam te praerepta leoni / pellis obit (Past. 4, 72-73), vö. Eleg. 22, 3-4: Fulva Cleonaei certe per terga Leonis / celsius aestivos sol agit acer equos. A másik átvétel a Guarino-panegyrikusból származik, melynek végleges változata csak 1469-ben készült el ugyan, első változatát azonban Janus már 1454 körül megírta, ${ }^{19}$ ferrarai költőbarátai tehát jól ismerhették: non pardum fugient lepores, non damma leonem (Past. 4, 64), vö. Paneg. Guar., Praef. 13: non tigrim cervus tremuit, non damma leonem. ${ }^{20}$ Legalábbis elgondolkodtató, hogy ugyanezen eclogában Boiardo azt az Aeneis-szöveghelyet is megidézi, amelyhez Servius fönt idézett asztrológiai okfejtése kapcsolódik: tunc nec sanguinei radiabit stella cometae, / nec vastum insanis consurget fluctibus aequor (Past. 4, 81-82). Ha az ifjú Boiardo ismerte Janus költeményeit, valószínü az is, hogy ezekhez nagybátyján keresztül jutott hozzá. Strozzi leírása mindenesetre megerősíti, hogy Janus elégiájában sem magáról a Venusról vagy a Iuppiterről van szó, hanem olyan üstökösről, mely a két jótékony bolygó valamelyikéből keletkezett. A korabeli humanista költészetben, bár nem gyakori, nem is egyedülálló ez a nézet. Így Naldo Naldi Volaterrais címü eposzában azt olvashatjuk, hogy a szerencsétlenséget hozó üstökösök az eleve ártalmas Saturnusból születnek: Namque ferunt nocuo ductos de sidere, tristis / quod Saturnus habet, diros arsisse cometas (1, 271-272).

Mind Bartha Lajos, mind Orbán Áron nyomós érvként hozza föl Bollók tézise ellen, hogy az üstökös föltűnését általánosan bajhozó előjelnek tekintették, mely természeti csapásokat, háborúkat, hatalomváltást jövendöl, míg az elégiában leírt, kedvező sugárzású (lumine dextro, 21), szelíd és békéltető természetü (placida temperie, 24) csillagtól Janus éppen ennek az ellenkezőjét várja, a balsors elhárítását, a Saturnus és Mars pusztító erőinek semlegesítését, a természet erőinek megzabolázását, a külpolitikai és a társadalmi béke elősegítését. Orbán Áron ezt olyan képtelenségnek tartja, hogy egyenesen az „ellenüstökös” kifejezéssel írja le. ${ }^{21}$ Láttuk azonban, hogy Janus és Strozzi asztrológiai fölfogása korántsem zárta ki az áldásos hatású üstökösök létezését. Annál kevésbé, mert ilyesmire a klasszikus római költészetben is találunk példát, mely azonban, úgy tűnik, elkerülte a Janus-kutatók figyelmét. Ez nem is csoda, hiszen a szövegszerű megfelelések, miként azt Török László aprólékosan föltárta, sokkal inkább Claudianus felé vezetnek. Jankovits László a De consulatu Stilichonis aranykorleírására hívta föl a figyelmet, mint amelytől Janus tudatosan eltér, ${ }^{22}$ míg Török László, később Zsoldos Endre, végül Orbán Áron is a Panegyricus dictus Honorio Augusto IV cos. híres

19 Iani Pannonii Opera quae manserunt omnia. Vol. III. Carmina epica. Fasc. I. Textus. Edidit, praefatus est et apparatu critico instruxit Iulius Mayer, similia addidit Ladislaus Török et Zaynab Dalloul. Budapest (2018) 16.

${ }^{20}$ E Janus-párhuzamokat Stefano Carrai kitűnő kiadása is számontartja: Matteo Maria Boiardo: Pastoralia. Testo critico, commento e traduzione di Stefano Carrai. Padova (1996).

${ }^{21}$ Orbán: $i . m$. (8. jegyz.) 222: „Interestingly, the negative effects (those which should be neutralized) altogether are typically those of the comets. In fact, one can say that Janus wants the star an anti-comet."

22 Jankovits: $i . m$. (4. j.) 239. 
szöveghelyében fedezte föl az elégia legfontosabb előképét. ${ }^{23}$ Nem kétséges, hogy Janus ezt a szöveget is szem elött tartotta:

\author{
Visa etiam medio populis mirantibus audax \\ stella die... \\ (Hon. IV cos. 184-185)
}

\title{
Una tamen longe reliquis audacior astris contempto Phoebi stella nitore micat. (Eleg. 22, 11-12)
}

Ezzel azonban a hasonlóságok ki is merülnek, hiszen Claudianus leírása a katasterismos tipikus példája: vagy Honorius megistenült anyja, vagy szintén isteni nagyapja jelent meg az égen (sive parens Augusta fuit, seu forte reluxit divi sidus avi..., 189-190), vagy csak a Nap volt olyan nagylelkű, hogy megosztotta az égboltot a Honorius látására siető csillagokkal (seu te properantibus astris / cernere sol patiens caelum commune remisit, 190-191). ${ }^{24}$ Legalább ennyire fontos előképnek tünik Calpurnius Siculus 1. eclogája. Azon jövendölésben, mely Nero hatalomra kerülését és a vele beköszöntő új aranykort hirdeti, s melyet maga Faunus vés bele egy bükkfa törzsébe, olvashatunk arról a szelíd fényü, barátságos üstökösről, mely Kr. u. 54 nyarán egy egész hónapig ragyogott az égen:
Cernitis ut puro nox iam vicesima caelo
fulgeat et placida radiantem luce cometem
proferat? ut liquidum niteat sine vulnere sidus? (Buc. 1, 77-79)

Erről a (kínai csillagászok által szintén adatolt) üstökösről ${ }^{25}$ megemlékezik Seneca is, a Janus által jól ismert Naturales Quaestionesben, mint olyan tüneményről, mely csattanósan rácáfolt az üstökösök rossz hírnevére (cometis detraxit infamiam, Nat. Quaest. 7,17). E magyarázat mögött a császár környezetében igen befolyásos egyiptomi Chairémónt sejthetjük, aki Nerónak ajánlotta az üstökösök különféle fajtáiról írott értekezését

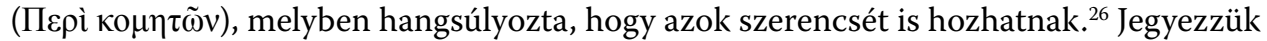
meg, nem volt ez nagyon ritka nézet. A Historia Augusta szerint Alexander Severus

${ }^{23}$ Török L.: Elferdített elégiák. In: Janus-arcok. Összegyüjtött tanulmányok, recenziók, forditások és kommentárok. Szerkesztette Mayer Gy. Budapest (2008) 149; Zsoldos: i. m. (9. j.) 44; Orbán: i. m. (8. j.) 222.

${ }^{24}$ J. Lehner: Poesie und Politik in Claudians Panegyrikus auf das vierte Konsulat des Kaisers Honorius: Ein Kommentar. Königstein (1984) 48-54.

${ }_{25}$ Az üstökös szakirodalmáról jó összefoglalót ad: Calpurni Siculi Eclogae. A cura di Maria Assunta Vinchesi. Firenze (2014) 145.

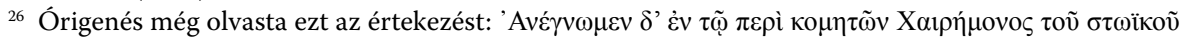

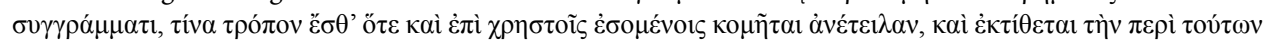

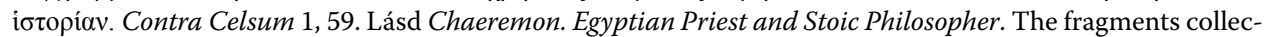
ted and translated with explanatory notes by P. W. van der Horst. Leiden (1987). 
születésekor, több más prodigium imperii mellett üstökös is föltünt az égen. ${ }^{27}$ Calpurnius bukolikus leírásához is előképül kínálkozott a 44-ben fölbukkanó sidus Iulium, mely Vergilius 9. eclogájában vetést növesztő, gyümölcsérlelő szerepben jelenik meg. ${ }^{28}$

Ismerhette-e Janus Calpurnius Siculus eclogáit? Aligha fér ehhez kétség, hiszen a Quattrocento második felében a bukolikus költészet rendkívül népszerűvé vált, a műfaj páratlan fölvirágzásában pedig nem csekély szerepe volt Guarino iskolájának. A tanítványokból egész kis bukolikus kör alakult. Strozzi és Boiardo mellett írt eclogákat Guarino fia, Battista, a modenai Caspar Tribrachus pedig egyenesen Vitéz Jánosnak ajánlotta a Calpurnius mintájára hét költeményből összeállított eclogáskönyvét. ${ }^{29}$ Calpurnius a legnépszerűbb költők közé tartozott, s talán érdemes megjegyezni, hogy e korban általánosan késő ókori auctornak tartották, értékelését tehát nem befolyásolta, hogy a legrosszabb emlékezetű császárok egyikét magasztalta költeményeiben. Calpurnius ismeretét igazolja Török László similiagyűjteménye, mely összesen nyolc szöveghelynél mutat ki lehetséges calpurniusi áthallást. ${ }^{30} \mathrm{~A}$ csak Calpurniusnál előforduló invida paupertas (Eleg. 7, 32, vö. Buc. 4, 156), azután a bullatae undae (Eleg. 11, 35, vö. Buc. 1, 11), a pagana iuventus (Eleg. 23, 3, vö. Buc. 4, 125), a patulis ilicibus (Eleg. 23, 12; vö. Buc. 5, 2) kétségtelenné teszi, hogy Janus alaposan tanulmányozta az eclogákat. A szó szerinti egyezések mellett azonban tematikus hasonlóságokat is találunk. Szembeszökő, de eddig nem regisztrált párhuzam, hogy mindkét költemény a szokatlan nyári hőség, a Nap zabolátlanul vágtató paripáinak képével kezdődik:

celsius aestivos sol agit acer equos (Eleg. 22, 4),

nondum Solis equos declinis mitigat aestas (Buc. 1, 1)

Egybevág az összehasonlításban megjelenített kártékony hatású üstökös leírása is:

\author{
Quantus conspicuo rutilans fulgore cometes \\ nuntiat horrenda bella cruenta iuba. (Eleg. 22, 13-14)
}

\footnotetext{
${ }^{27}$ Fertur die prima natalis toto die apud Arcam Caesaream stella primae magnitudinis visa et sol circa domum patris eius fulgido ambitu coronatus. (Alex. Sever. 13, 6)

${ }_{28}$ Daphni, quid antiquos signorum suspicis ortus? / ecce Dionaei processit Caesaris astrum, / astrum quo segetes gauderent frugibus et quo / duceret apricis in collibus uva colorem. (46-50.) „Der Komet tritt an die Stelle des Sirius, dem man traditionell einen Einfluß auf den ganzen Vegetationszyklus, ja auf das Weltgeschehen insgesamt zuschrieb." G. Baudy: Hirtenmythos und Hirtenlied. Poetica 25 (1993) 312.

${ }^{29}$ A bukolikus költészetről Guarino ferrarai iskolájában lásd A. Tissoni-Benvenuti: La restauration humaniste de l'églogue: L'école guarinienne à Ferrare. In: Le genre pastoral en Europe du XV au XVII siècle. Actes du Colloque internationale tenu à St. Étienne du 28 septembre au 1er octobre 1978. St. Étienne (1980) 25-34; L. Z. Simon: Die Eklogen des Caspar Tribrachus und die neue Blütezeit der Bukolik. In: Pietas non sola Romana. Studia memoriae Stephani Borzsák dedicata. Edd.: A. Czeglédy et al. Budapest (2010) 632-647.

${ }^{30}$ Eleg. 4, 25; 6, 12; 7, 32; 11, 22; 11, 35; 16, 33; 23, 3; 23, 12.
} 
Numquid utrumque polum, sicut solet, igne cruento
spargit et ardenti scintillat sanguine lampas?
At quondam non talis erat, cum Caesare rapto
indixit miseris fatalia civibus arma. (Buc. 1, 80-83)

Míg Calpurniusnál a Caesar halálát jelző, vérvörösen szikrázó lampas adja a rettenetes ellenképet, ${ }^{31}$ Janusnál, miként Bollók János írja, ez kétségtelenül az 1456-ban föltűnő, s egész Európát rémületbe ejtő Halley-üstökös. ${ }^{32}$ De számos egybeesést találunk a jóindulatú, szelíd fényü csillag megjelenítésében is:

$$
\begin{aligned}
& \text { clara sidus sub luce refulget (Eleg. 22, 1) } \\
& \text { puro caelo... / fulgeat (Buc. 1, 77-78) } \\
& \text { contempto Phoebi stella nitore micat (Eleg. 22, 12) } \\
& \text { liquidum niteat sine vulnere sidus (Buc. 1, 79) } \\
& \text { lumine dextro / pelle procul... (Eleg. 22, 21-22) } \\
& \text { placida corrige temperie (Eleg. } 22,24) \\
& \text { placida radiantem luce cometen (Buc. } 1,78)
\end{aligned}
$$

Értelmezésünket megerősíteni látszik, hogy a baljós, háborút hozó üstökösre jellemző vérvörös szín, miként Calpurniusnál, éles ellentétben áll azon jelzőkkel, melyekkel Janus a szokatlan égitestet jellemzi, hiszen a non tantum... noctis decus (20) aligha illenék egy vészjóslóan vöröslő égitestre, még kevésbé a placida temperies, s kivált nem ragyoghatna lumine dextro. Ráadásul ez utóbbi jelzős szerkezet, miként Török László kimutatta, csak Ennodius egy bibliai tárgyú költeményében fordul elő, tehát erős keresztény áthallása van. ${ }^{33}$ Nem lehet véletlen az sem, hogy a költemény záróképében Janus nem a rutilus, hanem a roseus jelzőt használja:

Omnia sic roseis cedant tibi sidera flammis, sic tuus occiduas nesciat ignis aquas. (Eleg. 43-44) $231-249$.

${ }^{31}$ L. D. Ginsberg: Allusive Prodigia: Caesar's Comets in Neronian Rome. TAPhA 150 (2020)

32 Bollók: i. m. (2. j.) 82 .

${ }^{33}$ Summe deum, sancti custos, qui culmine caeli / omina dextra facis, quae cernis lumine dextro (Carm. 1, 9, 108-109). 
A roseus már Vergilius óta a hajnalleírások szinte elmaradhatatlan eleme, ${ }^{34}$ Janus kortársai is untig ismételgetik epikus, elégikus és bukolikus tájleírásaikban. ${ }^{35}$ (A magyar humanista kényes ízlését mutatja, hogy ezt a toposzt elégiáiban egyáltalán nem használja, csak egy korai, s kétes hitelességű költeményben találunk rá egyetlen példát. ${ }^{36}$ ) A jelző azonban mindenképpen pozitív értelmű. A mondat alapján tehát („úgy hátráljon meg előtted minden rózsás lángú csillag”) az üstökös fénye nem izzóan vérvörös, legföljebb a hajnalpír színére emlékeztet. A fohászt és magát a költeményt is lezáró utolsó disztichon hangsúlyossá teszi ezt a képet. Janus bizonytalanságát, mi több, szorongását ugyanis, miként Bollók megállapítja, egyebek mellett éppen az üstökös színe okozta. Ptolemaios Tetrabiblosában azt olvashatta, hogy az Aréshoz sorolható üstö-

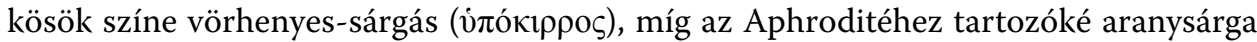

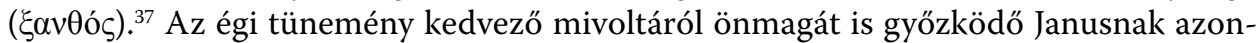
ban sikerült ezt az ellentmondást legalábbis tompítania, s azt sugallania, hogy a pirkadat barátságos színében lángoló üstökös nem keletkezhetett a Marsból. Egyben a régi költői közhelyet is merészen megújította, mert előtte aligha használta költő a roseus jelzőt üstökösleírásban. ${ }^{38}$

Calpurnius 1. eclogájának hatását sejthetjük az üstökösleírást követő fohászkodásban is. Ez két, egyaránt tíz sorból álló részre osztható. Az első (23-32) a természeti erők világát írja le, a második (33-42) pedig az emberi társadalmat, közelebbről Magyarország állapotát. Az első rész látszólagos kuszaságáról Bollók János bizonyította, hogy az Horatius nevezetes Odi profanumának (Carm. 3,1) két strófáját veszi mintául. ${ }^{39}$ A második tíz sort Jankovits László elemezte részletesebben. Ennek tárgya Magyarország belső fölvirágzása és külső védelme, fő motívuma a concordia, a társadalmi és politikai béke:

Per te vexato redeat concordia mundo, Ianus et aeterna comprimat arma sera. (Eleg. 35-36)

${ }^{34}$ Aurora in roseis fulgebat lutea bigis (Verg. Aen. 7, 26), vö. conscia nox sceleris roseo cedebat Eoo (Sil. It. 9, 180); Quis non Luciferum roseo cum Sole videri / credidit (Claud. Hon. III cos. 131-132); Fuderat in terras roseum iubar ignicomus sol (Iuvenc. Evang. 3, 1).

${ }_{35}$ Incipe laeta dies roseo procedere ab ortu, / igneaque extremus Lucifer astra fuget (Strozzi, Erot. 4, 1, 1-2); in roseis quotiens surgebat lutea bigis / Aurora (Naldi, Carm. var. 11, 25-26); cum primum roseis Aurora retexit olympum / curribus (Basinio, Astr. 2, 289-290); extulerat roseo Cynthius ore diem (Poliziano, Eleg. 7, 60); septima consurgens roseis aurora capillis (Mantuanus, Parth. 2, 1, 200); purpureumque diem roseis Aurora quadrigis / vectabat (Verino, Carl. 4, 198-199).

${ }^{36}$ Haec precor eveniant: tu nostris annue votis; / candida lux, roseis tuque veharis equis $(34,75-76)$.

37 Bollók: $i$. m. (2. j.) 80.

${ }^{38}$ Iohannes Ravisius Textor 1524-ben megjelent terjedelmes poétikai kézikönyve 18 jelzőt sorol föl az üstökösre, ezek: dirus, sanguineus, mutans regna, crinitus, candidus, fatalis, praeceps, tristis, fulgens, flammans, lucens, infelix, horrificus, turbans regna, rubicundus, igniger, clarus, rubescens. Ioannis Ravisii Textoris Nivernensis Epitheta, studiosis omnibus poeticae artis maxime utilia. Parrhisiis, apud Reginaldum Chauldiere (1524) 106.

39 Bollók: i. m. (2. j.) 84 . 
Jankovits itt két fö irodalmi előképet föltételez, az egyik Lucanus egy szöveghelye (laeta dies rapta est populis, concordia mundo / nostra perit, 9, 1097), a másik Vergilius 4. eclogájának híres sora: iam redit et Virgo, redeunt Saturnia regna (Ecl. 4, 6). Maga is hangsúlyozza azonban, hogy fontos különbségek vannak Vergilius jövendölése és Janus fohászkodása között. Az elégia világában a discordia, viszály, zűrzavar és külső háborús fenyegetés uralkodik, csak Janus fohászában jelennek meg „a nyomai ennek a tökéletes, mindent magától megtermő kornak”. ${ }^{40}$ Erre a föld termékenységét hozza példának: semina centeno reddat cum fenore tellus (Eleg. 22, 33). Ez azonban igen távol áll Vergilius aranykorának automatonmotívumától, mely éppen a földművelés teljes eltűnését föltételezi: non rastros patietur humus, non vinea falcem $(E c l$. 4, 40). Hasonló aranykorfölfogással találkozunk viszont Calpurniusnál. A korai császárkorban, így az ő eclogáiban is, az aranykor eszméje mindinkább elszakadt mitológiai-kozmológiai vonatkozásaitól, és politikai kategóriává vált, a Nero-kori propagandában pedig egyenesen a birodalom kormányzásának augustusi elveihez való visszatérést kezdte jelenteni. ${ }^{41}$ E politikai aranykor a törvényes rend helyreállításával valósul meg (legibus omne reductis / ius aderit, Buc. 1, 71-72), a mitikus aranykorral összeegyeztethetetlen földművelés és kereskedelem pedig nem visszafejlődik, miként Vergiliusnál, hanem fölvirágzik. Calpurnius 4. eclogájában találhatjuk meg a példátlanul bőséges termés motívumát is: coepit et uberior, sulcis fallentibus olim, / luxuriare seges tandemque legumina plenis / vix resonant siliquis... (Buc. 4, 113-115). Hasonlóképpen a beköszöntő béke nem az aranykor zavartalan, harcot hírből sem ismerő nyugalmát jelenti, hanem, miként Janusnál, a háborús állapotok megszűnését, az állam zavartalan virágzását: nullos iam Roma Philippos / deflebit (Buc. 1, 51-51); omnia Tartareo subigentur carcere bella (Buc.1, 52); candida Pax aderit (Buc.1, 54). Valószínübb tehát, hogy az elégia említett 35 sorának (per te vexato redeat concordia mundo sor) előképe sem Vergilius 4. eclogája, hanem Calpurnius azon szöveghelye, mely az igazság és jog istennőjének visszatérését hirdeti:

aurea secura cum pace renascitur aetas, et redit ad terras tandem squalore situque alma Themis posito...

(Buc. 1, 42-44)

Ebből következik azután a princeps és szenátus megromlott viszonyának helyreállítása, a polgárháborúval fenyegető viszonyok fölszámolása. A Seneca irányította propaganda ugyanis igyekezett Claudiust a hatalmat bitorló önkényúrnak beállítani, akinek zsarnoksága általános meghasonláshoz és zendülések sorához (publica discordia, Buc.1, 57) vezetett. ${ }^{42}$ Neróval azonban visszatért a törvényesség és a concordia ordinum, amikor a szenátorok nem a börtönben, hanem a curiában ülnek (nec carcere pleno / infelix raro

40 Jankovits: i. m. (4. j.) 239.

41 Takács L.: Nero. Politikus arcképvázlat. Piliscsaba (2010) 73.

42 A Calpurnius I. eclogájára is jellemző Claudius-ellenes propaganda történeti hátteréről kitűnő áttekintést nyújt T. Wiseman: Calpurnius and the Claudian Civil War. JRS 72 (1982) 57 skk. 
numerabit curia patres, Buc.1, 61-62). Említsük meg, hogy az eclogából korántsem hiányzik a parainetikus célzat: az ifjú uralkodónak, ha megjövendölt küldetését teljesíteni akarja, a múlt legendás hőseihez, Aeneashoz, Numához és az isteni Augustushoz kell hasonulnia. Hasonlóképpen parainetikus célzata van Janus sorainak is: a királynak nemcsak a hazán, hanem önmagán is uralkodnia kell. Ez azonban az uralkodó magasztalásának egyik bevett toposza, melyet aligha lehet Janus burkolt Mátyás-ellenes kritikájaként értelmezni. ${ }^{43} \mathrm{~A}$ fohász második fele tehát ugyanazon motívumokból épül föl, mint Calpurnius aranykorjóslaté. A zaklatott, polgárháborús állapotok megszűnnek, a társadalmi harmónia helyreáll, az uralkodó és az előkelők egyetértésben kormányozzák az országot:

Fac regem observent proceres, rex ipse fideli consilio procerum se regat et patriam. (Eleg. 22, 41-42)

Ha pedig a két költemény között e szövegszerü és tematikus megfelelések helytállóak, megkockáztathatjuk azt is, hogy Calpurnius 1. eclogája Janus egyik fontos ihletője volt. Ez korántsem meglepő, hiszen a politikai hatalomváltást és az új uralkodóval visszatérő aranykort ünneplő korabeli panegyrikusokban, így Naldo Naldinál vagy Boiardónál rendre Calpurnius hatásával találkozunk.

Janus elégiája mégis alapvetően különbözik e hol jobban, hol kevésbé sikerült dicskölteményektől. Jankovits László fontos észrevétele, hogy teljességgel hiányzik az egyik fö motívum, az aranykort elhozó messianisztikus hős alakja: „a költeményben nincs senki, akinek jelenléte biztosíték volna a fényes jövőre, jóllehet a versben megjelenik valaki, aki hagyományosan ilyen szerepet játszik: a király" ${ }^{44}$ Megerősíthetjük ezt egy másik calpurniusi párhuzammal: míg Calpurniusnál az új uralkodó állítja meg a romlást (afflictum melior deus auferet aevum, Buc. 1,73), Janus ezt csak a csodálatos üstököstől kérheti: afflictas respice Pannonias (Eleg. 22, 38). Ez megint különlegessé teszi az elégiát, hiszen a hasonló tárgyú, hatalomváltásról és elközelgő aranykorról szóló kortárs művek főszereplője mindig az új uralkodó, miként a fiatal Piccolomininál Filippo Maria Visconti, ${ }^{45}$ Strozzinál, Tribrachusnál és Boiardónál Borso d’Este, Naldo Naldinál Co-

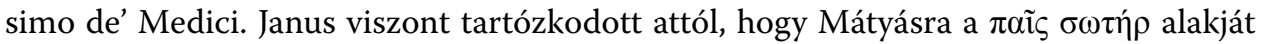
vetítse rá, nála a király valóban „a külső és belső konfliktusok által zaklatott világ szereplőinek egyike". ${ }^{46}$ Értelmezhetjük-e ezt úgy, hogy a költőnek már ebben az időben is voltak fönntartásai királyával szemben?

43 Jankovits: $i$. $m$. (4. j.) 241.

44 Jankovits: $i . m$. (4. j.) 241.

45 Piccolomini egyetlen eclogája 1432-ben keletkezett, a benne dicsért uralkodót sokáig Luxemburgi Zsigmonddal azonosították, lásd S. Prete: Pius II on Lake Orta. In: Studies in Latin Poets of the Quattrocento. Lawrence, University of Kansas (1978) 25-49.

46 Jankovits: $i$. m. (4. j.) 240. 
A történeti háttér ismeretében a megmentő hős hiánya némileg érthető, hiszen a Mátyás uralkodásának első éveit kísérő zűrzavar (Szilágyi Mihály ténykedése, a felső-magyarországi helyzet, a kaotikus belpolitikai viszonyok, Frigyes császár ellenkirálylyá választása, a török egyre aggasztóbb katonai ereje) kevés bizakodásra adott okot. ${ }^{47}$ Kubinyi András valószínűnek tartotta azt is, hogy ezekben az években Janus sem érezhette helyzetét igazán szilárdnak. Vitéz János és unokaöccse személyes sértettségére utalna, hogy 1460-ban jelen voltak azon a siklósi találkozón, ahol a börtönből kiszabadult Szilágyi Mihály megerősítette szövetségét a néhai Garai nádor családjával. A Janus által betöltött tisztségeket (királyi személynökség, cancellarius reginalis) Kubinyi jelentéktelennek tartotta, vagy egyenesen megkérdőjelezte, ${ }^{48}$ ám az újabb kutatás ezt a túlzott szkepticizmust nem igazolta. ${ }^{49} \mathrm{~A}$ királyi kancellárián, címétől függetlenül, Janus igen fontos megbízást kapott, a III. Frigyessel és Csehországgal kapcsolatos diplomáciai ügyeken dolgozott. 1462 tavasza pedig rendkívül kedvező fordulatot hozott. Április 3-án, Vitéz János tárgyalásainak eredményeként előkészítették a Frigyessel való békeszerződést, a császár ígéretet tett a Szent Korona visszaadására..$^{50}$ Május elején Giskrával is sikerül megállapodást kötni. Május 6-án Janus először jelenhetett meg a királyi tanács váci ülésén. Május 20-án Mátyás személyesen nyitotta meg a Budára összehívott, ritka jó hangulatú országgyủlést. Miként Fraknói îrja: „A király személye iránt lelkes hódolat, előterjesztései iránt kivételes áldozatkészség nyilvánúlt".51 Május 28-án a megállapodásokat közölték a pápai legátussal, az ünnepi szónoki tisztet pedig Janus töltötte be, aki már az országgyűlés napjaiban a rendek tolmácsa volt. Az ifjú humanista tehát joggal reménykedhetett abban, hogy az évek óta elhúzódó belpolitikai válság végre megoldódik, Mátyás uralma megszilárdul, saját pályája pedig fölívelőben van. E gyors és kedvező fordulat után az üstökös fölbukkanása joggal tölthette el aggodalommal, nem szólván a saját házában álló és regresszióban lévő Saturnus fenyegető pozíciójától. ${ }^{52}$ Kapóra jöhettek tehát azon asztrológiai tárgyú szövegek, így Servius kommentárja, Seneca Naturales Quaestionese, melyekkel még Guarino iskolájában megismerkedett, s melyek azt taglalták, hogy az üstökösöknek lehet jótékony, mi több, a kártékony bolygók erejét semlegesítő hatása is, de még inkább Calpurnius 1. eclogája, mely e jótékony hatást a concorida ordinum, a társadalmi rend és béke megszilárdulásával kapcsolta össze. A költő aggodalmait azonban mindez, úgy tűnik, nem oszlatta el teljesen. Túlságosan közeli emlék volt még a Halley-üstökös 1456-os föltűnése, s miként Bollók János írja, „az ebből fakadó félelem és féltés adja a versnek azt a lírai töltetét, mely a humanista apparátus kereteit

47 Kubinyi A.: Mátyás király. Budapest (2001) 42-56.

${ }^{48}$ Kubinyi A.: Vitéz János és Janus Pannonius politikája Mátyás uralkodása idején. In: Humanista müveltség Pannoniában. Szerk. Bartók I. - Jankovits L. - Kecskeméti G. Pécs (2000) 11-12.

49 A cancellarius regineus kérdéséhez lásd Gy. Mayer: King Matthias Corvinus' Epistolaria. In: Infima aetas Pannonica: Studies in Late Medieval Hungarian History. Ed. P. E. Kovács - K. Szovák. Budapest (2009) 230. 26. j.

${ }^{50}$ Fraknói V.: Vitéz János esztergomi érsek élete. Budapest (1879) 138-143.

${ }^{51}$ Fraknói V.: Hunyadi Mátyás király. Budapest (1890) 120.

52 Bollók: i. m. (2. j.) 82. 
szinte szétfeszítve, az elégiát már-már modern lírai költeménnyé teszi”. ${ }^{33} \mathrm{~S}$ talán ezzel magyarázható az uralkodó személyének háttérbe szorulása is. Az elégia drámai erővel fogalmazza meg azon létélményt, mely Janus elégiáiban oly sokszor visszatér: a földi világ és a földi halandók felsőbb erőknek való teljes kiszolgáltatottságát.

\section{SUMMARY}

So far there is no unanimity among researchers concerning the identification of the celestial body appearing in Janus Pannonius' elegy De stella aestivo meridie visa. János Bollók identified it with the comet observed in China in the summer of 1462 . However, his view was not generally accepted, and recent studies on the elegy have argued for an identification with the planet Venus. Based on the analysis of literary parallels so far left out of consideration, in our paper we claim that the description aimed to depict a comet. We examine the similar description found in Tito Vespasiano Strozzi's epic poem Borsias and show that his astrological views on comets with a beneficial influence were the same as that of Janus. This is further supported by the expressions taken over from Janus in the eclogues of Matteo Maria Boiardo. Researchers have also neglected the beneficial comet in Eclogue I of T. Calpurnius Siculus. Based on the examination of textual parallels we aim to prove that this eclogue was an important model for the elegy of Janus - its influence can not only be detected in the description of the comet but also in the invocation in the elegy alluding to motives of the Golden Age.

Keywords: Janus Pannonius, Calpurnius Siculus, Claudius Claudianus, Tito Vespasiano Strozzi, Matteo Maria Boiardo, humanist elegy, bucolic poetry, ancient and Renaissance astrology

\section{SIMON LAJOS ZOLTÁN}

ELTE BTK Ókortudományi Intézet, Latin Tanszék

simon.zoltan@btk.elte.hu

Open Access. A cikk a Creative Commons Attribution 4.0 International License (https://creativecommons.org/licenses/by/4.0) feltételei szerint publikált Open Access közlemény, melynek szellemében a cikk bármilyen médiumban szabadon felhasználható, megosztható és újraközölhető, feltéve, hogy az eredeti szerző és a közlés helye, illetve a CC License linkje és az esetlegesen végrehajtott módosítások feltüntetésre kerülnek. (SID_1)

53 Bollók: i. m. (2. j.) 82-83. 